\title{
MONOPOLI BISNIS KOPERASI SIMPAN PINJAM DI TINJAU DARI UNDANG - UNDANG NO. 25 TAHUN 1992 TENTANG PERKOPERASIAN
}

\author{
Afifudin Afifudin \\ Magister Hukum Universitas Semarang
}

\begin{abstract}
ABSTRAK
Tujuan dari penelitian ini adalah untuk menganalisa monopoli bsinis simpan pinjam. Koperasi adalah salah satu bentuk usaha yang selama ini dikenal pro rakyat dan mempunyai badan hukum di Indonesia. Koperasi lebih terlihat dari sisi kekeluargaan dan gotong royong untuk saling membantu anggotanya demi kesejahteraan bersama sesuai prinsip dasar koperasi yang diatur dalam undang - undang No 25 Tahun 1992 Tentang Perkoperasian. Koperasi simpan pinjam adalah merupakan salah satu dari beberapa jenis koperasi yang diatur dalam undang - undang No 25 Tahun 1992 Tentang Perkoperasian yang bertujuan untuk mensejahterakan anggota dan masyarakat yang non anggota. Akan tetapi kehadiran koperasi simpan pinjam pada saat ini seringkali di monopoli oleh pemilik modal dalam hal pendiriannya, keberadaannya, serta dalam hal pengelolaannya. Penelitian ini menggunakan metode pendekatan yuridis normatife atau hukum normatif. Dalam pasal 3 UU. No 25 tahun 1992 tentang Perkoperasian disebutkan bahwa, koperasi bertujuan memajukan kesejahteraan anggota pada khususnya dan masyarakat pada umumnya, serta ikut membangun tatanan perekonomian nasional, dalam rangka mewujudkan msayarakat yang maju, adil dan makmur berlandaskan Pancasila dan Undang-Undang Dasar 1945. Untuk memajukan anggotanya maka koperasi seperti halnya koperasi konsumen atau koperasi simpan pinjam tentunya tidak bisa mengambil margin yang banyak (untuk koperasi konsumen). Koperasi Simpan Pinjam merupakan suatu lembaga keuangan dan termasuk sebagai lembaga intermediary, meskipun demikian lembaga keuangan ini memiliki sifat yang khusus sesuai dengan prinsip - prinsip koperasi.
\end{abstract}

\section{Kata kunci: Monopoli; bisnis; koperasi}


e-ISSN : 2621-4105

\title{
THE BUSINESS COOPERATION MONOPOLY OF SAVING AND LOANS CONSIDERED OF LAW NO 25/1995 CONCERN OF COOPERATION
}

\author{
Afifudin Afifudin \\ Master of Law, University of Semarang
}

\begin{abstract}
The purpose of this study is to analyze the monopoly of savings and loan businesses. Cooperatives are a form of business that has been known to be pro-people and has legal entities in Indonesia. Cooperatives are more visible in terms of kinship and mutual cooperation to help each other members for the common welfare in accordance with the basic principles of cooperatives regulated in Act No. 25 of 1992 concerning Cooperatives. Savings and loan cooperatives are one of several types of cooperatives regulated in Act No. 25 of 1992 concerning Cooperatives which aims to prosper the members and non-member communities. However, the presence of savings and credit cooperatives is currently often monopolized by capital owners in terms of their establishment, their existence, and in terms of their management. This research uses the method of normative juridical approach or normative law. In article 3 of the Act. No. 25 of 1992 concerning Cooperatives stated that, cooperatives aim to promote the welfare of members in particular and society in general, as well as participate in building the national economic order, in order to realize an advanced, just and prosperous society based on Pancasila and the 1945 Constitution. then cooperatives like consumer cooperatives or savings and loan cooperatives certainly cannot take a large margin (for consumer cooperatives). The Savings and Loans Cooperative is a financial institution and is included as an intermediary institution, although this financial institution has special characteristics in accordance with cooperative principles.
\end{abstract}

Keywords: Monopoly; business; cooperative 
e-ISSN : 2621-4105

\section{A. PENDAHULUAN}

Bangsa Indonesia telah melakukan pembangunan untuk mewujudkan tujuan nasional, yaitu mewujudkan masyarakat yang adil dan makmur secara materiil dan spiritual berdasarkan Pancasila dan Undang-Undang Dasar 1945. Usaha yang telah dilakukan pemerintah tersebut salah satunya adalah meningkatkan taraf hidup masyarakat Indonesia, khususnya dalam bidang sosial dan ekonomi yakni dengan memberikan pinjaman melalui jalur perkreditan terhadap masyarakat yang membutuhkan tambahan modal. Wujud daripada hal tersebut salah satu sasaranya adalah koperasi. ${ }^{1}$ Indonesia merupakan Negara yang tergolong sebagai Negara berkembang, dimana dalam struktur perekonomiannya secara garis besar terdapat tiga pelaku ekonomi utama yaitu : Badan Usaha Milik Negara (BUMN), Badan Usaha Milik Swasta (BUMS), dan Koperasi, yang mana ketiga-tiganya diusahakan berkembang selaras agar tercipta masyarakat yang adil dan makmur. Dari ketiga pelaku ekonomi tersebut yang paling sesuai untuk hidup dan berkembang di Indonesia adalah Koperasi. Hal ini sesuai dengan Undang-Undang Dasar 1945 Pasal 33 ayat 1 sebagai berikut: Perekonomian disusun sebagai usaha bersama berdasarkan atas azas kekeluargaan. Untuk meyelaraskan usaha koperasi dengan perkembangan keadaan. Ketentuan tentang perkoperasian di Inonesia telah diperbaharui, yaitu dengan Undang-Undang Perkoperasian Nomor 25 Tahun 1992, yang merumuskan koperasi sebagai berikut : "Koperasi adalah badan usaha yang beranggotakan orang-orang atau badan hukum koperasi dengan melandaskan kegiatannya bedasarkan prinsip koperasi sekaligus sebagai gerakan ekonomi rakyat yang berdasarkan atas azas kekeluargaan". ${ }^{2}$

Di samping lembaga lain seperti bank atau pegadaian, koperasi sebagai urat nadi perekonomian bangsa Indonesia. ${ }^{3}$ Koperasi (Co-operatives) merupakan suatu organisasi ekonomi yang dijalankan oleh para anggota secara individual yang masing-masing memiliki satu suara dan ukuran kepemilikan yang sama sehingga bagian keuntungan yang akan diterima sama besarnya. Susunan keanggotaannya terdapat pada perseroan terbatas hanya proses pengambilan keputusan dalam koperasi lebih demokratis yang menonjol dalam koperasi adalah satu anggota satu suara. Koperasi simpan pinjam dan koperasi perumahan yang prinsip kerjanya sama dengan koperasi lainnya, keuntungan dibagi secara merata berdasarkan

${ }^{1}$ R.T Sutantya Raharja Hadhikusuma. Hukum Koperasi Indonesia, Jakarta PT Raja Grafindo Persada, 2000, Hlm 31

2 Darji Darmonodiharjo, Undang-Undang Dasar 1945, (Jakarta: Balai Pustaka, 1945), cetakan ke $3 \mathrm{hlm} .38$

${ }^{3}$ G. Kartasapoetra dan A. G Kartasanoetra dan kawan. Koperasi Indonesia yang Berdasarkan Pancasila dan UUD 1945, PT Rineka Cipta, Jakarta, 2001, hlm 11 
e-ISSN : 2621-4105

konstribusi. Tujuh prinsip koperasi, pertama keanggotaan bersifat terbuka, kedua satu anggota satu suara, ketiga perputaran modal terbatas, keempat alokasi surplus produksi disesuaikan atau konstribusi dari masing-masing anggota, kelima jasa penyedian uang tunai, keenam penekanan pada aspek pendidikan, dan ketujuh bersifat netral dalam soal agama dan politik. ${ }^{4}$

Secara umum koperasi dipahami sebagai perkumpulan orang yang secara sukarela mempersatukan diri untuk memperjuangkan peningkatan kesejahteraaan ekonomi mereka pada suatu perusahaan yang demokratis. ${ }^{5}$ Azas koperasi Indonesia adalah kekeluargaan dan kegotong royongan. Dengan berpegang teguh pada azas kekeluargaan dan kegotong royongan sesuai dengan kepribadian Indonesia, ini tidak berarti bahwa koperasi meninggalkan sifat dan syarat-syarat ekonominya. Koperasi Indonesia hendaknya menyadari bahwa di dalam dirinya terdapat suatu kepribadian Indonesia sebagai pencerminan dari garis pertumbuhan bangsa Indonesia yang ditentukan oleh kehidupan bangsa Indonesia.

Para pedagang kecil, salah satu bagian dari masyarakat golongan ekonomi lemah perlu mendapatkan bantuan terutama dalam hal tersedianya modal yang cukup untuk berusaha. Untuk itulah peran bank-bank Islam termasuk lembaga keuangan non bank seperti BMT maupun koperasi yang berdasar syariat Islam mengembangkan pemikiran untuk memberikan pembiayaan tanpa jaminan, karena BMT (Baitul Maal Waat tamwil) sebagai salah satu lembaga keuangan Islam dalam operasionalnya juga tidak menggunakan sistem bunga seperti yang lain dilakukan bank konvensional, BMT menerapkan sistem bagi hasil bagi para nasabahnya. ${ }^{6}$

Bagi koperasi azas gotong-royong berarti bahwa pada koperasi terdapat kesadaran semangat bekerjasama dan tanggung jawab bersama terhadap karya tanpa memikirkan kepentingan diri sendiri, melainkan selalu untuk kebahagiaan bersama. Sedangkan azas kekeluargaan mencerminkan adanya kesadaran dari hati nurani manusia untuk mengerjakan segala sesuatu dalam koperasi oleh semua untuk semua dibawah pimpinan pengurus. ${ }^{7} \mathrm{Di}$ tengah gejolak perekonomian yang semakin lama semakin tampak kompetitif, koperasi diharapkan dapat menempatkan diri sebagai salah satu kekuatan ekonomi yang sejajar dengan kekuatan ekonomi lain yang telah ada. Untuk mendukung gagasan ini diperlukan suatu tekad

\footnotetext{
${ }^{4}$ Arifinal Chaniago, Pengertian Koperasi, (Bandung : Angkasa, 1986), hlm.12.

${ }^{5}$ Revrisond Baswir, Koperasi Indonesia, Yogyakarta, BPFE - Yogyakarta, 2000, hlm 2

${ }^{6}$ Diah Sasikirana Retno Murniati, Muhammad Junaidi, Implementasi Akad Mudhorobah Pada Koperasi Simpan Pinjam Dan Pembiayaan Syariah Baitul Maal Wat Tamwil Binama Semarang, Jurnal Ius Constituendum Vol 2 No 1, Magister Hukum Universitas Semarang, 2017, Semarang, hlm 60.

${ }^{7}$ Pandji anaroga dan Ninik Widiyanti, Mananejemen Koperasi-Teori dan Praktek, (Jakarta: PT. Dunia Pustaka Jaya, 1995), cetakan ke 1, hlm. 8-10
} 
e-ISSN : 2621-4105

guna merombak organisasi yang seringkali dianggap berbentuk sosial, ciri-ciri kekeluargaan dalam koperasi dapat dilihat seperti azas untuk mengerjakan usaha secara bersama yang tumbuh dalam masyarakat lebih menonjol dari aspek-aspek ekonominya. Untuk mewujudkan harapan di atas selain rasa solidaritas, kebersamaan atau kekeluargaan yang selama ini merupakan sifat utama masyarakat Indonesia yang masih bersifat agraris ini, koperasi juga menghendaki adanya rasa individualitas.

Dalam hal individualitas dapat diartikan sebagai kesadaraan akan harga diri anggotaanggota koperasi. Dengan mengetahui dasar pemikiran atas bentuk koperasi di atas, disadari bahwa dalam usaha mengalihkan bentuk dari organisasi sosial ke dalam suatu kekuatan ekonomi yang tangguh. Koperasi terus akan menghadapi berbagai tantangan berupa hambatan-hambatan klasik seperti kurangnya modal, terbatasnya keahlian, sedikitnya tenaga manajerial dan sebagainya. ${ }^{8}$ Dalam kegiatan usaha yang dilakukan oleh suatu perusahan, modal merupakan faktor pendukung dalam mencapai perkembangan perusahaan tersebut. Dengan modal yang cukup dalam membiayai kegiatan usaha, maka dari hasil penjualan atau yang lazim disebut dengan pendapatan usaha dapat diperoleh dengan keuntungan yang tinggi. Sasaran ini akan dapat dicapai dengan dukungan penuh daripada anggotanya, di samping kerja keras dari para pengurus koperasi itu sendiri.

Pada umumnya bahwa untuk mendirikan koperasi bisa datang dari pihak yang berkepentingan atau bisa dari pemerintah. Mereka yang mempunyai kepentingan sendiri ialah mereka yang menjadi anggota koperasi sendiri bisa petani, nelayan, karyawan dan lain lainnya menurut jenis koperasinya, memenuhi syarat - syarat keanggotaan sebagai yang tersebut dalam anggaran dasar koperasi yang akan didirikan. Mereka ini dengan penuh kesadaran atas kehidupannya merasakan perlunya membentuk suatu koperasi sebagai suatu jalan keluar dari kesulitan hidupnya sehari - hari. ${ }^{9}$

Modal koperasi terdiri dan dihimpun dari simpanan-simpanan pokok, wajib dan sukarela para anggotanya (yang dalam hal ini dapat diterima pula simpanan sukarela dari bukan anggota), pinjaman-pinjaman, penyisihan - peyisihan hasil usaha (termasuk cadangancadangan) dan dari sumber-sumber lain. Dengan demikian dalam koperasi modal itu terdiri dari modal interen dan modal eksteren yang sama-sama potensial guna membiayai usaha dan pengembangan koperasi. Modal interen berasal dari simpanan-simpanan para anggotanya dan hasil usaha yang khususnya sebagai cadangan, sedangkan modal eksteren berasal dari

\footnotetext{
${ }^{8}$ Ninik Widiyanti, Manajemen Koperasi, (Jakarta: PT. Rineka Cipta, 2002), cetakan ke 5, hlm. 153-154

${ }^{9}$ Panji Anoraga. Dinamika Koperasi, (Jakarta: PT.RINEKA CIPTA, 1992), hlm. 71.
} 
e-ISSN : 2621-4105

pinjaman dan simpanan-simpanan (deposito) di luar keanggotaan yang jumlahnya tergantung dari kepercayaan yang dapat diberikan oleh koperasi itu sendiri. ${ }^{10}$

\section{B. PERUMUSAN MASALAH}

Berdasarkan latar belakang di atas, maka dapatlah dirumuskan permasalahan-permasalahan sebagai berikut:

1) Bagaimana keberadaan monopoli koperasi simpan pinjam yang ada pada saat ini di tinjau dari Undang - Undang No. 25 Tahun 1992?

2) Bagaimana kendala dan solusi atas adanya monopoli koperasi simpan pinjam dalam pengelolaan di tinjau dari Undang - Undang No. 25 Tahun 1992 ?

\section{PEMBAHASAN}

\section{Keberadaan monopoli koperasi simpan pinjam yang ada pada saat ini di tinjau dari} Undang - Undang No. 25 Tahun 1992.

Peraturan Menteri Koperasi dan Usaha Kecil dan Menengah (Permen Kop \& UMKM) Nomor 15/Per/M.KUKM/IX/2015 yang menyebutkan bahwa modal sendiri KSP terdiri dari simpanan pokok, simpanan wajib, cadangan yang disisihkan dari sisa hasil usaha, hibah dan simpanan lain yang memiliki karekteristik sama dengan simpanan wajib. Sedangkan Modal USP (Unit Simpan Pinjam) adalah modal tetap USP yang ditempatkan oleh koperasinya pada awal pendirian USP Koperasi, modal tidak tetap tambahan dari koperasi yang bersangkutan, dan cadangan yang disisihkan dari hasi usaha USP koperasi Sementara itu Permen Kop \& UMKM Nomor 11/Per/M.KUKM/2015 tentang Petunjuk Pemupukan Modal Penyertaan bagi Koperasi, maka Koperasi dalam hal ini KSP memiliki peluang yang besar untuk menghimpun dana yang dapat digunakan untuk membiayai dan mengembangkan usahanya tanpa harus melanggar peraturan yang ada. Hal ini dikarenakan modal penyertaan bagi Koperasi sebagaimana yang diatur dalam peraturan di atas, dapat berasal dari Pemerintah, Anggota, Masyarakat, Badan Usaha yang berbentuk Badan Hukum seperti BUMN/BUMD atau PT milik swasta, Badan Usaha yang bukan berbadan hukum seperti CV \& Firma maupun penyertaan modal yang berasal dari badan hukum lainnya seperti Yayasan dan lain sebagainya.

Koperasi Simpan Pinjam merupakan suatu lembaga keuangan dan termasuk sebagai lembaga intermediary, meskipun demikian lembaga keuangan ini memiliki sifat yang khusus sesuai dengan prinsip prinsip koperasi. Menurut Permen Kop \& UMKM Nomor

10 Karta Sapoerta, dkk, Praktek Pengelolaan Koperasi, (Jakarta: PT Rineka Cipta/Bina Adiaksara, 2003), cetakan ke 4, hlm. 45 
e-ISSN : 2621-4105

15/Per/M.KUKM/2015 khususnya pasal 19 disebutkan bahwa Kegiatan usaha simpan pinjam meliputi: menghimpun simpanan dari anggota; memberikan pinjaman kepada anggota, calon anggota koperasi yang bersangkutan, koperasi lain dan atau anggotanya; dan mengelola keseimbangan sumber dana dan penyaluran pinjaman.Calon anggota koperasi sebagaimana dimaksud pada ayat (1), dalam waktu selambat-lambatnya 3 (tiga) bulan wajib menjadi anggota koperasi. Kegiatan usaha simpan pinjam dengan koperasi lain dilakukan melalui kemitraan yang dituangkan dalam perjanjian tertulis.

Koperasi memiliki berbagai macam jenis seperti koperasi serba usaha, koperasi simpan pinjam dan sebagainya, koperasi ini ada yang berbasis konvensional dan berbasis syariah. Dalam kesehariannya praktek koperasi disamping melayani anggota juga melayani masyarakat umum yang biasanya dikemas sebagai calon anggota, sehingga hal ini sangat bertentangan dengan ketentuan yang ada. Penelitian ini lebih difokuskan pada Koperasi Simpan Pinjam Konvensional. Berdasarkan data yang ada di Dinas Koperasi \& UMKM Propinsi Jawa Tengah, jumlah di Kota Semarang adalah 104 KSP, baik yang berskala kecil, menengah maupu besar. Dinas Koperasi \& UMKM memilik kewenangan untuk melakukan pembinaan dan pengawasan terhadap Koperasi. Berkaitan dengan hal itu, dinas koperasi akan melakukan penilaian terhadap tingkat kesehatan koperasi simpan pinjam dan menggolongkannya dalam lima kategori yaitu : sehat, cukup sehat, kurang sehat, tidak sehat dan sangat tidak sehat. Kategori tadi didasarkan pada hasil perhitungan skoring dengan memperhatikan semua aspek keuangan, manajemen dan lain - lain. Dari 104 KSP yang ada, hanya 9,6 \% yang berkategori sehat, sedangkan sisanya memiliki kategori di bawah itu. KSP seharusnya memberikan pelayanan dan jasa mediasi dari anggota kepada anggota, namun dalam praktek sehari-hari KSP telah melampaui kewenangannyanya dengan menawarkan dan menerima jasa simpanan dari pihak non anggota dan menyalurkan pinjaman kepada non anggota. Sepak terjang yang seperti ini adalah mirip dengan apa yang dilakukan oleh pihak perbankan, sehingga patut diduga bahwa apa yang dilakukan oleh KSP adalah merupakan pelanggaran terhadap UU Perbankan.

Pengawasan dan Pembinaan yang lemah dari pihak berwenang dan aturan yang cukup longgar, terkadang dimanfaatkan oleh para pihak yang tidak bertanggungjawab untuk mendirkan KSP dan melakukan praktek-praktek yang curang dan merugikan masyarakat banyak dan menurunkan citra koperasi. KSP yang berstatus Cukup Sehat, Kurang Sehat, 
e-ISSN : 2621-4105

Tidak Sehat dan Sangat Tidak Sehat dimungkinkan terjadi karena pengurus yang kurang memiliki ketrampilan manajemen atau terbentur adanya kesulitan dalam permodalan dan pengelolaan piutang, sehingga berujung pada perkembangan usaha dan kesehatan KSP itu sendiri. ${ }^{11}$

Kenyataan dewasa ini menunjukkan, bahwa koperasi di Indonesia belum memiliki kemampuan untuk menjalankan peranannya secara efektif. ${ }^{12}$ Menurut UU Nomor 25 tahun 1992 tentang perkoperasian, dalam Pasal 40 bahwa modal koperasi terdiri atas modal sendiri dan modal pinjaman. Modal sendiri terdiri atas simpanan pokok, simpanan wajib, dana cadangan dan hibah. Sedangkan modal pinjaman bisa berasal dari anggota koperasi yang bersangkutan, koperasi lain, bank/lembaga keuangan, obligasi atau surat utang dan sumbersumber lain yang sah. Menurut pasal 42 disebutkan bahwa Koperasi juga dimungkinkan untuk memupuk dana dari modal penyertaan, yang pelaksanaannya diatur dengan peraturan pemerintah. Yang menjadi pertanyaan, bagaimana sesungguhnya praktek yang dilakukan oleh kalangan pelaku Koperasi Simpan Pinjam. Bahwa ekuitas KSP selama ini berasal dari:

1. Simpanan Pokok - dilakukan pada saat pertama kali menjadi anggota.

2. Simpanan Wajib - dibayar setiap bulan dengan jumlah tertentu.

3. Dana Cadangan yang dibentuk dengan persetujuan RAT (Rapat Anggota Tahunan).

Dari hasil analisis dapat direduksi ke dalam rangkuman seperti yang tersaji sebagai berikut :

a) KSP tidak bisa mengandalkan pemupukan dana atau modal yang berasal dari para anggota yang berupa Simpanan Pokok dan Simpanan Wajib;

b) Terdapat ketidak disiplinan anggota dalam memenuhi simpanan wajib, namun pada sisi yang lain, mereka lebih cenderung banyak menuntut hak sebagai anggota;

c) Penambahan jumlah anggota sebagai salah satu upaya pemupukan ekuitas menghadapi kendala aturan baik yang berasal dari internal maupun eksternal;

d) Manajer/Kepala Cabang KSP meskipun sudah memiliki sertifikasi kompetensi yang dikeluarkan oleh Lembaga Sertifikasi Profesi Koperasi, tidak bisa berbuat banyak dalam mengembangkan KSP karena segala sesuatu telah diatur oleh pengurus dan dikemas dalam keputusan RAT. Akibatnya mereka harus memiliki kreativitas guna mensiasati peraturan dan keputusan RAT;

${ }^{11}$ Sri Purwantini, Endang Rusdianti dan Paulus Wardoyo, Kajian Pengelolaan Dana Koperasi Simpan Pinjam Konvensional Di Kota Semarang, Jurnal Dinamika Sosial Budaya, Volume 18, Nomor 1, Universitas Semarang, 2016, Semarang. hlm. 134.

${ }^{12}$ Pandji anoraga dan Ninik widiyanti, $\mathrm{Op}$ - Cit, Hlm.127 
e) Adanya perilaku dari pengurus dan pengawas koperasi, yang lebih mendominasi dan bertindak seakan-akan koperasi tersebut adalah" milik pribadi”, sehingga prinsip-prinsip koperasi tidak dapat berjalan seperti yang diharapkan. ${ }^{13}$

Berdasar paal 4 dari UU No 25 tahun 1992, disebutkan bahwa fungsi koperasi yaitu meliputi:

1. Membangun dan mengembangkan potensi dan kemampuan ekonomi anggota pada khususnya dan masyarakat pada umumnya untuk meningkatkan kesejahteraan ekonomi dan sosial.

2. Berperan serta secara aktif dalam upaya mempertinggi kualitas kehidupan manusia dan masyarakat.

3. Memperkokoh perekonomian rakyat sebagai dasar kekuatan dan ketahanan perekonomian nasional dengan koperasi sebagai sokogurunya.

4. Berusaha untuk mewujudkan dan mengembangkan perekonomian nasional yang merupakan usaha bersama berdasarkan atas asas kekeluargaan dan demokrasi ekonomi. ${ }^{14}$

\section{Kendala Dan Solusi Atas Adanya Monopoli Koperasi Simpan Pinjam Dalam Pengelolaan Di Tinjau Dari Undang - Undang No. 25 Tahun 1992.}

Sejalan dengan semakin majunya sarana komunikasi, sedikit banyak membawa pengaruh pada pola kehidupan di pedesaan. Oleh karenanya pola konsumsi yang begitu tinggi di perkotaan, kemudian ditiru di pedesaan. Sebagai akibatnya peningkatan produksi dipedesaan yang memang sudah lambat, menjadi semakin berkurang dengan pengaruh pola konsumsi tersebut, sehingga banyak mengurangi tabungan masyarakat yang pada dasarnya tabungan merupakan kekuatan atau modal dalam pembangunan ekonomi. Jika hal ini dibiarkan berlangsung maka boleh jadi masyarakat di pedesaan pada akhirnya nanti akan lebih mengutamakan pola konsumtif sekalipun untuk itu harus mempergunakan uang hasil pinjaman yang semestinya untuk hal - hal yang bersifat produktif. Mengingat luasnya aspek pembangunan yang dicanangkan, maka sebagai implementasinya, bangun struktur kekuatan ekonomi indonesia pada tiga kekuatan utama: badan usaha milik negara (BUMN), badan usaha milik swasta (BUMS) dan koperasi. Walaupun ketiga kekuatan ini mempunyai lahan garapan yang sedikit banyaknya berbeda, tetapi diharapkan ketiganya dapat saling mengisi atau saling menunjang dalam konteks menuju kepada tujuan pembangunan nasional indonesia, dan tentunya juga diharapkan dalam perjalanan selanjutnya, ketiga kekuatan itu tetap memegang teguh prinsip atau asas kekeluargaan sebagaimana dimaksud.

\footnotetext{
${ }^{13}$ Sri Purwantini, Endang Rusdianti dan Paulus Wardoyo, Op - Cit, hlm. 137
}

${ }^{14}$ Ibid, hlm.133 
Melihat idealnya, maka dari tiga kekuatan ekonomi tersebut yang paling memungkinkan menjadi basis pertumbuhan ekonomi masyarakat pedesaan adalah koperasi. Dengan pertimbangan sebagai berikut:

1. Koperasi bukanlah badan usaha yang tujuan utamanya berorientasi profit, meski tidak menampiknya;

2. Sifat kegotongroyongan masyarakat pedesaan dianggap lebih tinggi dibanding dengan masyarakat perkotaan. Tetapi jika menyimak perkembanagannya koperasi belum berperan sebagaimana yang diharapkan. Masyarakat desa masih belum bisa menghargai koperasi sebagai sebuah kekuatan yang secara ekonomis mampu mengangkat taraf hidupnya. ${ }^{15}$

Koperasi adalah suatu perkumpulan yang beranggotakan orang-orang atau badan-badan yang memberikan kebebasan masuk atau keluar anggota dengan bekerjasama secara kekeluargaan menjalankan usaha, untuk mempertinggi kesejahteraan jasmaniah para anggotanya, definisi ini mengandung arti bahwa:

a) Perkumpulan koperasi bukan merupakan perkumpulan modal (bukan akumulasi modal) akan tetapi persekutuan sosial.

b) Sukarela untuk menjadi anggota, netral terhadap aliran dan agama

c) Tujuannya mempertinggi kesejahteraan jasmaniah anggota-anggota dengan kerjasama secara kekeluargaan. ${ }^{16}$

Pada penjelasan tersebut koperasi memiliki ciri - ciri khusus yaitu:

a. Beberapa orang disatukan oleh kepentingan ekonomi yang sama.

b. Tujuan mereka, baik bersama dengan tindakan perseorangan adalah memajukan kesejahteraan bersama dengan tindakan bersama secara kekeluargaan.

c. Alat untuk mencapai tujuan itu adalah badan usaha yang dimiliki, dibiayai, dan dikelola bersama.

d. Tujuan utama badan usaha itu adalah meningkatkan kesejahteraan semua anggota perkumpulan. ${ }^{17}$

Dari berbagai definisi dan pengertian koperasi, pada umumnya terdapat beragam unsur yang terkandung, tetapi pada pokoknya sama yaitu:

1) Merupakan perkumpulan modal orang, bukan semata perkumpulan modal.

2) Adanya kesamaan baik dalam tujuan, kepentingan maupun dalam bentuk kegiatan sosial, menyebabkan lahirnya beragam bentuk dan jenis koperasi.

\footnotetext{
${ }^{15}$ Pandji Anoraga dan Ninik widiyanti, Dinamika Koperasi, rineka cipta, Jakarta, 2007, Hlm.192

${ }^{16}$ Ninik Widiyanti, Koperasi dan Perekonomian Indonesia ( Jakarta: Bina Adiaksara, 2003), cetakan ke 4, hlm. 1

${ }^{17}$ Abdulkadir Muhammad, Hukum Koperasi, Alumni, Bandung, 1982, hlm 120
} 
3) Merupakan usaha yang bersifat sosial, tetapi tetap bermotif ekonomi.

4) Bukan bertujuan untuk keuntungan badan koperasi itu sendiri, tetapi untuk kepentingan kesejahteraan koperasi.

5) Diurus bersama, dengan semangat kebersamaan dan gotong royong.

6) Netral.

7) Demokratis

8) Menghindari persaingan antar anggota.

9) Merupakan suatu system (terintegrasi dan terorganisasi).

10) Sukarela.

11) Mandiri dan kepercayaan diri.

12) Keuntungan dan manfaat sama, propordional dengan jasa yang diberikan.

13) Pendidikan

14) Moral.

15) Pengaturan beragam untuk setiap Negara, tetapi dengan satu prinsip yang tetap sama, yaitu prinsip - prinsip koperasi. ${ }^{18}$

Pada bab II, Bagian Kedua, Pasal 3 UU No. 25 Tahun 1992 tentang Perkoperasian, tertuang tujuan koperasi Indonesia seperti berikut :

"Memajukan kesejahteraan anggota pada khususnya dan masyarakat pada umumnya serta ikut membangun tatanan perekonomian nasioanal dalam rangka mewujudkan masyarakat yang maju, adil, dan makmur berlandaskan Pancasila dan Undang - Undang Dasar 1945" Pasal 4 UU No. 25 Tahun 1992 tentang Perkoperasian diuraikan fungsi dan peran koperasi Indonesia seperti berikut:

1) Membangun dan mengembangkan potensi dan kemampuan ekonomi anggota pada khususnya dan masyarakat pada umumnya untuk meningkatkan kesejahteraan ekonomi dan sosialnya.

2) Berperan serta secara aktif dalam upaya mempertinggi kualitas kehidupan manusia dan masyarakat.

3) Memperkokoh perekonomian rakyat sebagai dasar kekuatan dan ketahanan perekonomian nasional dengan koperasi sebagai soko gurunya.

4) Berusaha untuk mewujudkan dan mengembangkan perekonomian nasional yang merupakan usaha bersama atas dasar asas kekeluargaan dan demokrasi ekonomi. ${ }^{19}$

Dalam hal ini Koperasi kredit didirikan bertujuan untuk memberikan kesempatan kepada anggota - anggotanya memperoleh pinjaman dengan mudah dengan ongkos (bunga) yang ringan. Itulah sebabnya koperasi ini disebut dengan koperasi kredit. Akan tetapi untuk memberikan pinjaman atau kredit itu koperasi memerlukan modal. Modal koperasi yang utama adalah simpanan anggota sendiri. Dari uang simpanan yang dikumpulkan bersama -

\footnotetext{
${ }^{18}$ Andjar Pachta,op.cit, hlm 20

${ }^{19}$ Ibid, Hlm 40
} 
sama itu diberikan pinjaman kepada anggota yang perlu dibantu. Oleh karena itu, maka koperasi kredit lebih tepat disebut koperasi simpan pinjam. ${ }^{20}$

Koperasi simpan pinjam atau koperasi kredit adalah salah satu jenis koperasi yang mempunyai kegiatan utama adalah menyediakan jasa penyimpanan dan peminjaman dana kepada anggota koperasi dengan tujuan memajukan kesejahteraan anggota koperasi dan juga masyarakat. Pada saat ini banyak orang yang masih belum memahami betapa pentingnya peran koperasi, banyak orang menganggap koperasi hanyalah lembaga keuangan biasa. Berdasarkan pasal 1 ayat (1) Undang-Undang Nomor 25 Tahun 1992 tentang Perkoperasian "koperasi adalah badan usaha yang beranggotakan orang-seorang atau badan hukum koperasi dengan melandaskan kegiatannya berdasarkan prinsip koperasi sekaligus sebagai gerakan ekonomi rakyat yang berdasarkan atas asas kekeluargaan. ${ }^{21}$

Menurut undang - undang koperasi menyebutkan megenai sumber modal koperasi yang terdiri dari beberapa jenis yaitu simpanan - simpanan baik pokok, wajib maupun sukarela dan cadangan yang dikumpulkan dari SHU yang merupakan kekayaan koperasi. Di samping itu koperasi juga memiliki modal yang bersifat potensial yang didasarkan pada sikap anggota terhadap koperasinya. Modal ini dapat besar dan dapat pula kecil nilainya berkaitan dengan besar/ kecilnya kesadaran orang dalam berkoperasi. Selain sumber seperti diuraikan diatas, yang disebut juga sebagai sumber modal intern. Koperasi dapat pula menambah modal yang berasal dari sumber ekstern yang berasal dari pinjaman atau simpanan - simpanan/ deposito dari luar keanggotaan koperasi termasuk pula dalam sumber ekstern ini misalnya berbagai fasilitas yang berasal dari pemerintah. ${ }^{22}$

Koperasi pada dasarnya adalah badan hukum sebagaimana badan usaha lainnya seperti CV, PT, Firma dan sebagainya. Namun di sisi lain koperasi dituntut untuk mensejahterakan anggotanya. Di satu sisi koperasi jelas membutuhkan keuntungan untuk kelangsungan usahanya namun di sisi lain keberadaan berdasarkan didirikannya adalah untuk memajukan kesejahteraan anggotanya. Ketika koperasi dipandang sebagai badan usaha maka tentunya koperasi (dalam hal ini pengelola) dituntut untuk mengoptimalkan keuntungan dengan cara mendapatkan pendapatan yang sebesar-besarnya. Namun mengingat semangat didirikannya koperasi adalah untuk memajukan anggotanya maka koperasi seperti halnya koperasi konsumen atau koperasi simpan pinjam tentunya tidak bisa mengambil margin yang banyak (untuk koperasi konsumen) atau tidak dapat menetapkan tingkat pengembalian yang besar (untuk koperasi simpan pinjam). Sebab koperasi ini tentunya beroperasi untuk melayani

\footnotetext{
${ }^{20}$ Ibid, hlm. 22.

${ }^{21}$ R.T. Sutantya Rahardja Hadhikusuma, 2000, Hukum Koperasi Indonesia, Jakarta:PT Raja Grafindo Persada, hal 59-60, 74.

${ }^{22}$ Sudarsono dan Edilius, Koperasi dalam teori dan praktik, Rineka Cipta, Jakarta, 2010.Hlm.116
} 
konsumen yang notabene adalah anggotanya sendiri. ${ }^{23}$ Dalam UU. No 25 tahun 1992 tentang Perkoperasian pasal 3 disebutkan bahwa, koperasi bertujuan memajukan kesejahteraan anggota pada khususnya dan masyarakat pada umumnya, serta ikut membangun tatanan perekonomian nasional, dalam rangka mewujudkan msayarakat yang maju, adil dan makmur berlandaskan Pancasila dan Undang-Undang Dasar 1945. ${ }^{24}$

Tujuan koperasi simpan pinjam menawarkan penyimpanan dan pinjaman adalah agar supaya anggota dapat menabung pada koperasi tersebut sehingga anggota dapat merasa tenang dalam menyimpan uangnya selain itu dalam hal peminjaman, anggota juga dapat melakukan peminjaman kepada pihak koperasi dengan bunga yang kecil untukm embangun usaha atau bisnis yang diinginkan, namun koperasi juga harus memikirkan tentang adanya azas keyakinan atas kemampuan bagi calon nasabah yang akan melakukan peminjaman untuk melunasinya sehingga tidak ada kerugian bagi koperasi dan anggota penyimpan lainnya. Inilah alasan mengapa koperasi sangat memegang peranan penting dalam pertumbuhan ekomomi masyarakat Indonesia. Perbedaannya dengan Bank adalah bank menawarkan peminjaman uang yang bunganya relatif tinggi sehingga kebanyakan masyarakat yang melakukan peminjaman banyak terjadi kemacetan untuk membayar angsuran bahkan tidak mampu lagi untuk melunasinya hingga terjadi wanprestasi. Menurut Undang-Undang Nomor 17 Tahun 2012, Pasal 1 (ayat 15) menyatakan: "Koperasi Simpan Pinjam adalah Koperasi yang menjalankan usaha simpan pinjam sebagai satu-satunya usaha". ${ }^{25}$ Berdasarkan prinsip-prinsip koperasi yang disebutkan diatas maka dapat penulis simpulkan dan sekaligus analisis bahwa prinsip-prinsip koperasi setidak tidaknya terdiri atas;

1. Keanggotaannya bersifat sukarela dan terbuka; prinsip ini mengandung arti bahwa seseorang untuk menjadi atau tidak menjadi anggota koperasi tidak boleh dipaksakan, jadi atas kesadaran sendiri.

Globalisasi adalah keterbukaan dan kebebasan, prinsip koperasi ini sangat sesuai. Adanya sifat keterbukaan ini membuat koperasi tidak mengenal batas-batas dan diskriminasi apapun.

2. Prinsip pengelolaan dilakukan secara demokratis Pengelolaan disini tidak terbatas pada manajemen saja namun meliputi pengawasannya.

Setiap anggota mempunyai hak dan kewajiban yang sama didalam koperasi, hak mengusulkan, mengoreksi, dan bertanya tentang pengelolaan koperasi serta sekaligus untuk dipilih dan memilih menjadi pengurus ataupun pengawas. Dalam masa globalisasi seperti pada saat ini membuat koperasi jarang dilirik oleh para pemilik modal, sebab

\footnotetext{
${ }^{23}$ https://media.neliti.com/media/publications/17234-ID-kritik-terhadap-koperasi-sertasolusinya-sebagai-media-pendorong-pertumbuhan-usa.pdf diakses pada 4 Juli 2018

${ }^{24}$ Arifin Sitio \& Halomoan Tamba. Koperasi Teori dan Praktik ( Jakarta: Erlangga, 2001), hlm. 19

${ }^{25}$ Undang-Undang Perkoperasian. UU No. 17 tahun 2012,( Jakarta: Sinar Grafika), hlm. 3
} 
berapapun seseorang memilik dana, namun tetap saja memiliki satu suara, sehingga koperasi bebas investasi dari pihak yang mempunyai modal besar.

3. Prinsip pembagian sisa hasil usaha dilakukan secara adil sebanding dengan besarnya jasa usaha masing - masing anggota Anggota adalah pengguna jasa koperasi.

Didalam koperasi keuntungan dalam bentuk uang namanya sisa hasil usaha. Sisa hasil usaha adalah selisih antara pendapatan yang diperoleh dengan biaya-biaya yang dikeluarkan dalam pengelolaan usaha. Setiap anggota yang memberikan partisipasi aktif dalam usaha akan mendapatkan bagian keuntungan dari pada anggota yang tidak aktif. Koperasi bukan badan usaha yang berwatak kapitalis sehingga sisa hasil usaha yang dibagikan kepada anggota tidak berdasarkan modal yang dimiliki anggota, tetapi berdasarkan kontribusi jasa usaha yang diberikan anggota kepada koperasi.

4. Prinsip pemberian balas jasa terbatas modal yang dimiliki anggota. Anggota adalah pemilik koperasi dan sekaligus sebagai pemanfaat jasa. Modal yang disetorkan kepada koperasi pada dasarnya untuk melayani anggota dan dari pelayanan itu koperasi diharapkan mendapatkan nilai lebih dari pendapatan dikurangi biaya. Karena itu balas jasa terhadap modal yang diberikan kepada anggota atau sebaliknya juga terbatas yang tidak sematamata didasarkan kepada besarnya modal yang diberikan kepada koperasi. Yang dimaksud terbatas adalah pemberian balas jasa atas modal yang ditanamkan disesuaikan dengan kemampuan yang dimiliki koperasi. Jasa yang terbatas artinya bahwa suku bunga atas modal dalam koperasi tidak melebihi suku bunga yang berlaku di pasar. Sehingga jika dikaitkan dengan masa globalisasi, fungsi modal pada koperasi berbeda dengan lembaga keuangan lainnya, sebab koperasi tidak hannya sekedar mencari keuntungan semata (profit motive), akan tetapi dipergunakan untuk pemanfaatan anggota (benefit profit). Prinsip ini adalah prinsip yang paling unik, sebab badan usaha lain tidak memiliki prinsip ini.

5. Prinsip kemandirian koperasi.

Koperasi harus mampu berdiri sendiri dalam hal mengambil keputusan usaha dan organisasi. Kemandirian artinya juga kebebasan yang bertanggung jawab, otonom, swadaya dan keberanian mempertanggung jawabkan segala tindakan sendiri dalam mengelola usaha dan organisasi. Mandiri artinya dapat berdiri sendiri tanpa tergantung pada pihak lainnya. Prinsip ini adalah pendorong bagi koperasi untuk meningkatkan keyakinan akan kekuatan sendiri untuk mencapai tujuan. Pada masa globalisasi seperti pada saat ini prinsip kemandirian sangat diperlukan dalam pengembangan organisasidan usaha. Dengan prinsip ini koperasi dapat bersaing pada masa apapun, karena tidak tergantung dengan pihak lain.

6. Prinsip pendidikan perkoperasian.

Keberhasilan koperasi berkaitan erat dengan kualitas yang baik dan berwawasan luas dari semua lini, apakah pada level anggota, pengurus, pengawas dan tentunya pengelola beserta karyawanya. Untuk mewujudkan kondisi yang demikian maka pendidikan perkoperasian sangat diperlukan. Dengan sarana pendidikan ini, anggota khususnya dan organ koperasi lainya dipersiapkan dan dibentuk menjadi anggota loyalis, yang memahami, mengerti dan menghayati nilai-nilai dan prinsip-prinsip serta praktek-praktek berkoperasi. Dengan pendidikan ini koperasi akan mampu bersaing di masa globalisasi, karena anggota memahami, mengerti dan menghayati senangnya menjadi anggota koperasi karena mempunyai keunggulan yang tidak dimilki lembaga dan badan usaha lain.

7. Kerjasama antar koperasi.

Bidang usaha koperasi bermacam - macam, ada yang usahanya sama ada pula bidang usahanya yang beraneka. Masing-masing usaha tersebut disadari bahwa kemampuan 
antara satu koperasi dengan kemampuan koperasi lainya tentunya tidak sama. Kerjasama antar koperasi baik pada tingkat kabupaten, propinsi, nasional dan bahkan internasional dimaksudkan untuk saling memanfaatkan kelebihan dan melemahkan kekurangan pada masing-masing koperasi. Sehingga hasil yang akan dicapai akan lebih mudah dan dicapai secara optimal.

Apalagi pada masa globalisasi pada saat ini efektitas dan efisiensi sangat dibutuhkan. Dengan kerjasama antar koperasi diharapkan akan saling menunjang dan mendayagunakan kelebihan antar Koperasi, artinya tercipta sinergitas. Penerapan nilai dan prinsip-prinsip koperasi merupakan hal yang sangat fundamental dalam suatu Undang-Undang Koperasi. Roh atau pembeda koperasi dengan badan usaha lainya terletak pada roh yang disebut dengan prinsip-prinsip koperasi. Dalam menganalisis penerapan prinsip koperasi pada UndangUndang No. 25 Tahun 1992 dan Undang-Undang No. 17 Tahun 2012 harus disandarkan pada;

1. Pada hukum dasar negara Indonesia yaitu Undang-Undang Dasar 1945 khususnya pada alenia keempat Pembukaan UUD 1945 “...Kemudian dari pada itu untuk membentuk suatu Pemerintahan Negara Indonesia yang melindungi segenap bangsa Indonesia dan seluruh tumpah darah Indonesia dan untuk memajukan kesejahteraan umum".

2. Pada Pasal 33 ayat (1) UUD 1945: "perekonomian disusun sebagai usaha bersama berdasar atas asas kekeluargaan".

3. Pada Pasal 33 ayat (4) UUD 1945: "Perekonomian nasional diselenggarakan berdasar atas demokrasi ekonomi dengan prinsip kebersamaan, efisiensi berkeadilan, berkelanjutan, berwawasan lingkungan, kemandirian, serta dengan menjaga keseimbangan kemajuan dan kesatuan ekonomi nasional"; dan

4. Pada pengertian koperasi dan prinsip - prinsip koperasi yang ditetapkan oleh Internatiaonal Cooperative alliance (ICA); badan atau organisasi dunia yang lain, dan dari para ahli atau tokoh perkoperasian.

Undang-Undang No. 25 Tahun 1992, Pasal 1 menyebutkan koperasi adalah badan usaha yang beranggotakan orang-seorang atau badan hukum koperasi dengan melandaskan kegiatannya berdasarkan prinsip koperasi sekaligus sebagai gerakan ekonomi rakyat yang berdasarkan atas asas kekeluargaan. Sedangkan Undang-Undang No. 17 Tahun 2012 Pasal 1 menyebutkan bahwa yang dimaksud koperasi badan hukum yang didirikan oleh orang perseorangan atau badan hukum koperasi, dengan pemisahan kekayaan para anggotanya sebagai modal untuk menjalankan usaha, yang memenuhi aspirasi dan kebutuhan bersama dibidang ekonomi, sosial dan budaya sesuai nilai dan prinsip koperasi. Dari pengertian 
e-ISSN : 2621-4105

koperasi sebagaimana dalam Undang-Undang No. 25 Tahun 1992 bahwa kata "orang seorang" bersifat "individualitas" yang artinya adalah sadar dan memahami bahwa harga dirinya untuk berusaha secara bersama. Berbeda dengan rumusan pada Undang-Undang No. 17 Tahun 2012 dimana kata "Orang perseorangan" bersifat "individualisme" yang artinya mendahulukan kepentingan sendiri dan mengingkari untuk bekerjasama (cooperative). Dengan demikian dapat dianalisis bahwa pengertian koperasi pada Undang-Undang No. 25 Tahun 1992 sesuai dengan alenia keempat pembukaan UUD 1945, Pasal 33 ayat (1) dan 33 ayat (4) serta sesuai pengertian koperasi yang ditetapkan ICA. Sedang pengertian koperasi menurut Undang-Undang No. 17 Tahun 2012 bertentangan dan tidak sesuai dengan pembukaan pada alenia keempat Undang - Undang Dasar 1945 dan bertentangan dengan prinsip-prinsip koperasi Namun mengenai status koperasi sebagai badan hukum. Hal ini sebagaimana termuat dalam penjelasan Undang-Undang No. 17 Tahun 2012, bahwa sejarah perjalanan koperasi di Indonesia sudah cukup panjang, dan karenanya usaha perbaikan dari aspek kualitas utamanya dalam menghadapi perubahan tata perekonomian nasional dan global, maka status koperasi sebagai badan hukum, merupakan sesuatu yang perlu diatur dalam Undang-Undang Koperasi. Koperasi sebagai badan hukum memang mengalami perubahan pada konsep dasar koperasi. Keberlangsungan suatu koperasi sejatinya terletak pada anggota, karena anggota adalah pemilik dan sekaligus pengguna jasa karena koperasi ada karena ada manusia sebagai anggota, sedangkan badan hukum adalah subyek hukum yang adanya karena dianggap sebagai subyek hukum atau badan hukum adalah subyek hukum buatan atau subyek hukum rekaan .Tentang prinsip-prinsip koperasi pada Undang-Undang No.25 Tahun 1992 yang meliputi;

1. Keanggotaan bersifat sukarela dan terbuka;

2. Pengelolaan dilakukan secara demokratis;

3. Pembagian sisa hasil usaha dilakukan secara adil sebanding dengan besarnya jasa usaha masing-masing anggota;

4. Kemandirian; serta ditambah prinsip pendidikan perkoperasian; dan kerjasama antar koperasi. ${ }^{26}$

Undang-Undang Nomor 17 Tahun 2012 tentang Perkoperasian yang menggantikan UndangUndang Nomor 25 Tahun 1992. Sayangnya Undang-Undang ini jauh panggang dari api untuk memajukan koperasi. Yang ada malah melemahkan koperasi dan bertentangan dengan

26 Aji Basuki Rohmat, analisis penerapan prinsip-prinsip koperasi dalam undang-undang koperasi, Jurnal Pembaharuan Hukum, Volume II No. 1, 2015. 
e-ISSN : 2621-4105

UndangUndang Dasar. Undang-Undang ini baru dua tahun berjalan kemudian dibatalkan secara keseluruhan oleh Mahkamah Konstitusi. Undang-Undang Koperasi dianggap sudah kehilangan ruhnya sebab tidak lagi mendasari pada prinsip-prinsip koperasi. Koperasi didesain seperti halnya perusahaan kapitalisme yang semata-mata mencari keuntungan, bukan bertujuan untuk mensejahterakan anggotanya. Bahkan koperasi dalam definisinya menjadi lahan utuk mencari keuntungan oleh oranag peroranagan. Dalam pengujian ini Mahkamah mengabulkan permohonan pemohon dan membatalkan keseluruhan Undang-Undang nomro 17 Tahun 2012 dengan beberapa pertimbangan. Pertama, berkaitan dengan definisi koperasi yang diatur dalam Pasal 1 angka 1 Undang-Undang Nomor 17 Tahun 2012 tentang yang menyatakan "Koperasi adalah badan hukum yang didirikan oleh orang perseorangan atau badan hukum Koperasi, dengan pemisahan kekayaan para anggotanya sebagai modal untuk menjalankan usaha, yang memenuhi aspirasi dan kebutuhan bersama di bidang ekonomi, sosial, dan budaya sesuai dengan nilai dan prinsip Koperasi." ${ }^{27}$ Mahkamah memberikan tanggapan bahwa Rumusan koperasi adalah (sebagai) badan hukum tidak mengandung pengertian substantif mengenai koperasi sebagaimana dimaksud Pasal 33 ayat (1) UUD 1945 dan Penjelasannya yang merujuk pada pengertian sebagai bangun perusahaan yang khas. ${ }^{28}$ Menurut Mahkamah koperasi adalah mengenai siapa koperasi itu, atau dengan perkataan lain, rumusan yang mengutamakan koperasi dalam perspektif subjek atau sebagai pelaku ekonomi, yang merupakan sebagian dari sistem ekonomi. Untuk maksud tersebut dirumuskan dengan kata atau frasa, perkumpulan, organisasi ekonomi, atau organisasi ekonomi rakyat. Atau, paling tidak dalam koperasi dirumuskan sebagai "badan usaha". ${ }^{29}$ Sehingga rumusan koperasi dalam Undang-Undang Nomor 17 Tahun 2012 yang tidak menunjukkan sebagai pelaku ekonomi, adalah bertentangan dengan UUD karena mengandung individualisme. Kedua, mengenai pengangkatan pengurus non-anggota. Adanya pengaturan tersebut menghalangi atau bahkan menegasikan hak anggota koperasi untuk menyatakan pendapat, memilih, dan dipilih serta nilai kekeluargaan, bertanggung jawab, demokrasi, dan persamaan yang menjadi dasar koperasi. ${ }^{30}$ Koperasi adalah suatu organisasi yang dibangun dan dikembangkan berdasarkan perkumpulan orang, tujuannya adalah kesejahteraan orang perorangan. Jika yang

27 Pasal 1 angka 1 Undang-Undang Nomor 17 Tahun 2012 tentang Perkoperasian (Lembaran Negara Republik Indonesia Tahun 2012 Nomor 212, Tambahan Lembaran Negara Republik Indonesia Nomor 5355)

28 Putusan Mahkamah Konstitusi Nomor 028/PUU-XI/2013 Tentang Pembatalan UndangUndang Nomor 17 Tahun 2012 Tentang Perkoperasian. yang dibacakan pada 28 Mei 2014. hlm. 241.

29 Ibid.

${ }^{30}$ Ibid., hlm. 245. 
akan membuat keputusan dalam pengelolaan adalah diluar anggota maka hal tersebut merupakan penyimpangan pada prinsip fundamental koperasi. Koperasi diharapkan tumbuh semakin baik dengan dibarengi kapasitas anggota koperasi yang mumpuni dalam mengurus koperasi. Untuk menjadikan koperasi sebagai organisasi yang profesional justru yang harus dibangun adalah anggota koperasi supaya menjadi tenaga professional. ${ }^{31}$ Untuk mewujudkan hal tersebut, tentu prinsip pendidikan dan pelatihan kepada anggota koperasi memainkan peran yang penting. Ketiga, berkenaan dengan modal koperasi. Dalam pengaturan UndangUndang a quo mengatur modal koperasi adalah Setoran Pokok dan Sertifikat Modal Koperasi sebagai modal awal selain itu juga dapat berasal dari hibah, modal penyertaan, modal pinjaman yang berasal dari anggota, dll. Terhadap ketentuan yang menyatakan bahwa setoran Pokok dibayarkan oleh Anggota pada saat yang bersangkutan mengajukan permohonan sebagai Anggota dan tidak dapat dikembalikan, ${ }^{32}$ adalah tidak dapat dibenarkan. Setoran pokok dalam koperasi harus dilihat sebagai wujud keputusan seseorang untuk menggabungkan diri secara suka rela sebagai anggota koperasi, jadi bila anggota tersebut memutuskan untuk keluar atau berhenti karena suatu alasan maka adalah wajar bila simpanan pokok tersebut ditarik kembali. ${ }^{33}$ Berkaitan dengan sertifikat modal yang mewajibkan anggota membeli, hal tersebut tidak sesuai dengan prinsip kesukarelaan dan keterbukaan. Hal ini berarti, orientasi koperasi telah bergeser ke arah kumpulan modal, yang dengan demikian telah mengingkari jati diri koperasi sebagai perkumpulan orang dengan usaha bersama sebagai modal utamanya. ${ }^{34}$ Dengan adanya pengaturan ini, maka koperasi akan dikhawatirkan kehilangan kekhasannya dalam pengambilan keputusan penting. Sedangkan pengaturan sertifikat modal yang ketika keluar tidak dapat dijual ke luar, tetapi harus dibeli sesama anggota atau oleh koperasi. Hal tersebut pada dasarnya sama dengan pengaturan setoran pokok. terdapat unsur paksaan di dalamnya. Bagaimana kalau sesama anggota tidak mau membeli, atau uang koperasi tidak mencukupi. ${ }^{35}$ Hal tersebut merugikan anggota Koperasi. Hal terakhir berkaiatan dengan modal koperasi adalah penyertaan. Hal tersebut harus dihindari sebab membuka intervensi pihak luar, termasuk pemerintah dan pihak asing, melalui permodalan tanpa batas. ${ }^{36}$ Koperasi sebagai perkumpulan orang dengan demikian menjadi

${ }^{31}$ Ibid.

${ }^{32}$ Pasal 67 ayat (1) Undang-Undang Nomor 17 Tahun 2012 tentang Perkoperasian (Lembaran Negara Republik Indonesia Tahun 2012 Nomor 212, Tambahan Lembaran Negara Republik Indonesia Nomor 5355)

${ }^{33}$ Putusan Mahkamah Konstitusi Nomor 028/PUU-XI/2013, Op.cit., hlm 247.

${ }^{34}$ Ibid. hlm. 247.

35 Ibid.

${ }^{36}$ Ibid., hlm. 249. 
e-ISSN : 2621-4105

tidak berbeda dengan Perseroan Terbatas sebagai kumpulan modal, atau bahkan sebagai Perseroan Terbatas terbuka yang go public yang menghimpun modal sebanyak-banyaknya dengan tanpa batas dengan resiko terbukanya peluang intervensi dari pihak di luar koperasi. ${ }^{37}$ Keempat, Larangan Pembagian Surplus Hasil Usaha Yang Berasal Dari Transaksi Dengan Non-Anggota. Terdapat ketidakadilan terkait dengan hak dan kewajiban, yaitu ketika koperasi mengalami surplus hasil usaha anggota tidak berhak atas tapi ketika koperasi mengalami defisit hasil usaha, baik disebabkan oleh transaksi dengan anggota atau nonanggota, anggota wajib menyetor sertifikat modal koperasi sebagai tambahan modal. ${ }^{38}$ Dalam pengaturan tersebut, koperasi seakan menempatkan dirinya sebagai entitas yang terpisah dari anggotanya. Padahal apa yang dimiliki koperasi seharusnya dipergunakan untuk mensejahterakan anggotanya, karena memang demikian tujuan berkoperasi. Kelima, tentang jenis-jenis koperasi. Dalam pengaturan ini, koperasi dipaksa untuk memilih salah satu jenis yang ditentukan dalam undang-undang ini. Pengaturan ini tidak sesuai fakta di lapangan yang berkaitan dengan perkembangan koperasi. membatasi jenis kegiatan usaha koperasi telah memasung kreativitas koperasi untuk menentukan sendiri jenis kegiatan usaha, yang bisa jadi, berseiring dengan perkembangan ilmu pengetahuan, teknologi, budaya, dan ekonomi, berkembang pula jenis kegiatan usaha untuk memenuhi kebutuhan ekonomis manusia. ${ }^{39}$ Pengaturan ini telah jelas ingin mengkerdilkan keberadaan koperasi. Jika suatu korporasi (PT) diperkenankan untuk membentuk konglomerasi, kenapa justru Koperasi harus dibatasi lapangan usahanya. Hal tersebut menjadikan ketidak adilan bagi pelaku dan penggerak koperasi. Padahal, banyak koperasi serba usaha (multi purpose cooperative) justru berhasil. Dengan segala pertimbangan di atas, maka tepat sekiranya Mahkamah Konstitusi membatalkan keseluruhan UU koperasi. Pengaturan yang berkaitan dengan prinsip fundamental justru berlawanan dengan identitas koperasi itu sendiri. Mahkamah Konstitusi telah menyelamatkan arah politik hukum pengaturan perkoperasian di Indonesia.

\section{PENUTUP}

Dalam pasal 3 UU. No 25 tahun 1992 tentang Perkoperasian disebutkan bahwa, koperasi bertujuan memajukan kesejahteraan anggota pada khususnya dan masyarakat pada umumnya, serta ikut membangun tatanan perekonomian nasional, dalam rangka mewujudkan msayarakat yang maju, adil dan makmur berlandaskan Pancasila dan Undang-Undang Dasar

\footnotetext{
37 Ibid.

${ }^{38}$ Ibid., hlm. 250.

${ }^{39}$ Ibid. hlm. 251.
} 
1945. Namun mengingat semangat didirikannya koperasi adalah untuk memajukan anggotanya maka koperasi seperti halnya koperasi konsumen atau koperasi simpan pinjam tentunya tidak bisa mengambil margin yang banyak (untuk koperasi konsumen) atau tidak dapat menetapkan tingkat pengembalian yang besar (untuk koperasi simpan pinjam). Sebab koperasi ini tentunya beroperasi untuk melayani konsumen yang notabene adalah anggotanya sendiri. Koperasi di Indonesia belum memiliki kemampuan untuk menjalankan peranannya secara efektif Pengawasan dan Pembinaan yang lemah dari pihak berwenang dan aturan yang cukup longgar, terkadang dimanfaatkan oleh para pihak yang tidak bertanggungjawab untuk mendirkan KSP dan melakukan praktek-praktek yang curang dan merugikan masyarakat banyak dan menurunkan citra koperasi. Koperasi Simpan Pinjam merupakan suatu lembaga keuangan dan termasuk sebagai lembaga intermediary, meskipun demikian lembaga keuangan ini memiliki sifat yang khusus sesuai dengan prinsip - prinsip koperasi.

\section{DAFTAR PUSTAKA}

\section{BUKU}

R.T Sutantya Raharja Hadhikusuma, 2000, Hukum Koperasi Indonesia, PT Raja Grafindo Persada, Jakarta.

Darji Darmonodiharjo, 1945, Undang-Undang Dasar 1945, Balai Pustaka, cetakan ke 3, Jakarta.

G. Kartasapoetra dan A. G Kartasanoetra dan kawan, 2001, Koperasi Indonesia yang Berdasarkan Pancasila dan UUD 1945, PT Rineka Cipta, Jakarta.

Arifinal Chaniago, 1986, Pengertian Koperasi, Angkasa, Bandung.

Revrisond Baswir, 2000, Koperasi Indonesia, BPFE, Yogyakarta.

Pandji anaroga dan Ninik Widiyanti, 1995, Mananejemen Koperasi-Teori dan Praktek, PT. Dunia Pustaka Jaya, cetakan ke 1, Jakarta.

Ninik Widiyanti, 2002,Manajemen Koperasi, PT. Rineka Cipta, cetakan ke 5, Jakarta.

Panji Anoraga, 1992, Dinamika Koperasi, PT.RINEKA CIPTA, Jakarta.

Karta Sapoerta, dkk, 2003, Praktek Pengelolaan Koperasi, PT Rineka Cipta/Bina Adiaksara, cetakan ke 4, Jakarta.

Pandji anoraga dan Ninik widiyanti, 2007, Dinamika Koperasi, rineka cipta, Jakarta.

Ninik Widiyanti, 2003, Koperasi dan Perekonomian Indonesia, Bina Adiaksara, cetakan ke 4, hlm. 1, Jakarta.

Abdulkadir Muhammad, 1982, Hukum Koperasi, Alumni, Bandung.

R.T. Sutantya Rahardja Hadhikusuma, 2000, Hukum Koperasi Indonesia, PT Raja Grafindo Persada, Jakarta.

Sudarsono dan Edilius, 2010, Koperasi dalam teori dan praktik, Rineka Cipta, Jakarta.

https://media.neliti.com/media/publications/17234-ID-kritik-terhadap-koperasi-sertasolusinya-sebagai-media-pendorong-pertumbuhan-usa.pdf 
Monopoli Bisnis Koperasi Simpan Pinjam Di Tinjau Dari

e-ISSN : 2621-4105

Arifin Sitio \& Halomoan Tamba, 2001, Koperasi Teori dan Praktik, Erlangga, Jakarta.

\section{JURNAL}

Aji Basuki Rohmat, 2015, Analisis Penerapan Prinsip-Prinsip Koperasi Dalam UndangUndang Koperasi, Jurnal Pembaharuan Hukum, Volume II No. 1.

Diah Sasikirana Retno Murniati, Muhammad Junaidi, Implementasi Akad Mudhorobah

Pada Koperasi Simpan Pinjam Dan Pembiayaan Syariah Baitul Maal Wat Tamwil

Binama Semarang, Jurnal Ius Constituendum Vol 2 No 1, Magister Hukum Universitas Semarang, 2017, Semarang. http://dx.doi.org/10.26623/jic.v2i1.542

Sri Purwantini, Endang Rusdianti dan Paulus Wardoyo, Kajian Pengelolaan Dana Koperasi Simpan Pinjam Konvensional Di Kota Semarang, Jurnal Dinamika Sosial Budaya, Volume 18, Nomor 1, Universitas Semarang, 2016, Semarang. 